\title{
Mechanical ventilation and heat recovery for low carbon retrofitting in
} dwellings

\author{
Phil F. G. Banfill ${ }^{1 *}$, Sophie A. Simpson ${ }^{1}$, Mark C. Gillott ${ }^{2}$, Jennifer White ${ }^{2}$ \\ ${ }^{1}$ Heriot-Watt University, Edinburgh, UK \\ ${ }^{2}$ The University of Nottingham, Nottingham, UK \\ * Corresponding author. Tel: +44 (0)131 451 4648, E-mail: P.F.G.Banfill@hw.ac.uk
}

\begin{abstract}
The ventilation heat loss in a typical unimproved UK dwelling is approximately equal to the conduction loss; therefore draught-proofing measures should form part of any energy refurbishment package. This will improve the building's air permeability but risks incurring additional energy costs associated with the need to provide controlled ventilation to maintain indoor air quality. This paper aims to determine the point at which the air permeability of the building improves the energy performance by enough to justify the increase in energy associated with the installation of mechanical ventilation with heat recovery (MVHR). A 1930's style semi-detached house, representative of a large proportion of solid wall dwellings in the UK, has been improved by a package of measures including MVHR. The building air tightness plays a critical role in reducing the building energy consumption and $\mathrm{CO}_{2}$ emissions.
\end{abstract}

Keywords: Retrofitting, Building Simulation, Mechanical Ventilation, Heat Recovery

\section{Introduction}

The UK has the oldest housing stock in the developed world with over 8.5 million properties over 60 years old1. The consequence of this is that building energy performance was not a concern at time of construction, therefore space heating dominates as a result of poor heat transfer characteristics associated with the building envelope and high infiltration rates. Of the 25 million dwellings in the UK, 34\% are solid-wall dwellings and responsible for $50 \%$ of the total UK domestic sector $\mathrm{CO}_{2}$ emissions ${ }^{2}$. CALEBRE (Consumer-Appealing Low Energy technologies for Building Retrofitting) is a $£ 2$ million research project, funded jointly by Research Councils UK Energy Programme and E.On. The project aims to establish a validated, comprehensive refurbishment package for reducing UK domestic $\mathrm{CO}_{2}$ emissions, whilst being acceptable and appealing to householders. As part of this project, a newlyconstructed occupied test house (the E.On house), specially built to 1930s standards and located on the campus of the University of Nottingham, is being used to evaluate retrofit solutions specifically targeted at solid-wall properties (classified as 'hard-to-treat'). Currently a number of improvements to the thermal properties of the construction and glazing fittings have been applied, in addition to a series of draught-proofing measures to improve the building air-tightness. An air permeability test is carried out after the application of each measure, and the ongoing energy performance of the building is recorded using a comprehensive monitoring system.

As the air tightness of the building improves it will become necessary to introduce a controlled ventilation system to maintain the indoor air quality (IAQ). As part of this research project a mechanical ventilation system with heat recovery (MVHR) has been installed and the impact on the building performance with regards to energy performance and IAQ is being monitored. The combined effects of improving the air tightness and installing MVHR reduces the building's space heating demand by decreasing infiltration and recovering thermal energy from the exhaust air to preheat the supply air. These savings come at the expense of the energy associated with the system's continuous operation; therefore there is a delicate balance between energy conservation and energy consumption associated with the system. 
This paper reports a preliminary study to understand the relationship between energy savings attributable to the MVHR system and whole house air tightness, and to determine the critical value of air permeability above which MVHR is ineffective as a means of energy saving in the dwelling.

\section{Building Air Tightness}

Findings generally support the notion that dwellings in more severe climates, such as Sweden, Norway and Canada are built more airtight, where the primary aim is to conserve energy and improve thermal comfort ${ }^{3}$. This level of air tightness necessitates a method of controlled ventilation and MVHR is generally installed as standard. The UK experiences a milder climate and dwellings are predominantly less airtight ${ }^{4}$, relying on infiltration combined with natural ventilation to provide the necessary air change rate to maintain indoor air quality. Boost extract is employed to remove high levels of pollutants at the point of production, but this strategy cannot guarantee a sufficient level of ventilation throughout the year. The consequences of this could be a build-up of pollutants, and conditions which permit the development of allergens ${ }^{5}$, whereas the installation of a mechanical ventilation system can help to mitigate this risk.

In modern society, people spend up to $90 \%$ of their time in an artificial environment ${ }^{6}$, whether it is a dwelling, workplace or transport vehicle. The ventilation of these spaces plays a critical role in maintaining indoor air quality and ensuring the well being and comfort of the occupant. An insufficient supply of fresh air can be a contributor to 'sick building syndrome', where occupants may be susceptible to a range of symptoms such as lethargy, headaches and respiratory problems. Improvements to building air tightness over the last two decades are thought to have contributed to a degradation in indoor air quality where ventilation has been reduced or poorly addressed. An effective ventilation strategy plays an essential role in introducing outdoor air, to dilute contaminants, and promote air movement within the occupied space.

Moisture, although in itself innocuous, is considered a pollutant within the built environment as it is continuously emitted by occupants and the processes they carry out in their day to day activities. As the moisture levels increase, so too does the risk of condensation forming on areas with cool surface temperatures, which can lead to the degradation of the building fabric, as well as other problems such as spores of mould and fungi. This can pose a health hazard causing allergies and illness such as asthma, rhinitis and conjunctivitis ${ }^{5}$. A ventilation strategy plays a key role in controlling humidity levels which can be the driving force behind the specified flow rate.

\section{Methodology}

A model of the E.On house was built using dynamic thermal modelling software IES Virtual Environment. The Test Reference Year (TRY) weather data for Nottingham was applied and used to predict the annual building energy consumption. Templates were created for each room type, specifying values for internal gains and corresponding diversity profiles. This was based on information detailed for domestic buildings in the NCM database ${ }^{7}$, which also provided room heating set-points and domestic hot water consumption. This information was consistent for all analyses.

A series of studies were carried out to determine the critical performance parameters of the MVHR system and whole house air tightness to ensure a net reduction in building energy: 
- An initial study considers the energy performance of the E.On house in its original state, and the performance associated with the application of each retrofit measure

- Subsequent studies consider the energy performance associated with an MVHR unit specified to minimum building standards at varying levels of air tightness, and compares this with system components specified to best practice performance standards.

The 'leakiness' of the building is determined by carrying out an air permeability test, or 'fanblower door test' ${ }^{8}$ which creates a differential pressure between the indoor and external environment. Numerous researchers have tried to link this empirically tested value to a background infiltration rate. Kronvall ${ }^{9}$ developed a rule of thumb method, dividing the tested air change rate by 20, whereas Dubrul ${ }^{10}$ increased the divisor range to between 10 and 30, depending on the exposure of the site. Sherman ${ }^{11}$ produced a complex model which incorporated a number of influencing parameters including climate zone, wind shielding, height of the house and size of cracks, whereas Jukisalo ${ }^{12}$ further developed this to include leakage distribution and balance of ventilation strategy.

Energy modelling is a detailed and time consuming process if the set-up is to accurately represent the building design and operation, therefore a degree of simplification has been applied to the modelling to provide an initial indication of the impact the variables have on the building performance and energy savings achieved. After assessing the site exposure, Kronvall's rule of thumb has been applied to the analyses to determine the background infiltration rate based on the measured air permeability values. This information will be used to select a number of investigations to consider in more detail, based on information obtained from the extensive measuring and monitoring which is continuing on the house. This preliminary report focuses on modeled output and measured data will be reported later.

\section{Results and Discussion}

\subsection{Application of retrofit measures to the E.On House}

The following investigation considers the annual building performance of the E.On House. Table 1 summarises the series of improvements, and the air permeability values tested at 50Pa. These are detailed in units of $\mathrm{m}^{3} / \mathrm{m}^{2}$.h, and corresponding values in ach ${ }^{-1}$. Notice the poor workmanship which resulted in only a small change in air permeability between stage 1 and 2, and the extensive detailed interventions necessary to achieve low air permeability in this house.

Figure 1 shows the heat losses occurring when the peak space heating load occurs in the E.On house. The improved thermal properties applied in stage 1 halve the external conduction losses, but there is little change in the infiltration losses due to only a marginal improvement in the building air tightness. Infiltration now forms a greater proportion of the overall heat loss, and the introduction of the MVHR system has increased the building air change rate, adding to the load placed on the space heating system. As more draught proofing measures are applied for stage 2, the tested air permeability is significantly reduced contributing to a considerable decrease in infiltration losses. The stage 3 draught-proofing measures provide yet further reductions. 
Table 1. E.On House Series of retrofit measures

\begin{tabular}{|c|c|c|c|}
\hline Stage & Description of work carried out & $\begin{array}{c}\text { Air } \\
\text { Permeability } \\
\left(\mathbf{m}^{3} / \mathbf{m}^{2} . \mathbf{h}\right) \\
\end{array}$ & $\begin{array}{c}\text { Air } \\
\text { Permeability } \\
\left(\text { ach }^{-1}\right) \\
\end{array}$ \\
\hline $\begin{array}{l}\text { Base } \\
\text { Case }\end{array}$ & $\begin{array}{l}\text { Single glazed windows, uninsulated walls, floor } \\
\text { and roof space, no draught-proofing }\end{array}$ & 15.57 & 14.85 \\
\hline 1 & $\begin{array}{l}\text { Double Glazing, wall and loft insulation, draught } \\
\text { proofing applied to most windows and doors. } \\
\text { Installation of MVHR system }\end{array}$ & 14.31 & 13.65 \\
\hline 2 & $\begin{array}{l}\text { Draught proofing throughout house re-done as } \\
\text { inadequate installation previously, and extended to } \\
\text { remaining windows and vents. }\end{array}$ & 9.84 & 9.39 \\
\hline 3 & $\begin{array}{l}\text { Service risers sealed. Covers fitted to door locks, } \\
\text { pipe work envelope penetrations sealed (radiators, } \\
\text { water pipes etc), Kitchen fan removed and bricked- } \\
\text { up. Sealing around boiler flue. }\end{array}$ & 8.6 & 8.21 \\
\hline
\end{tabular}

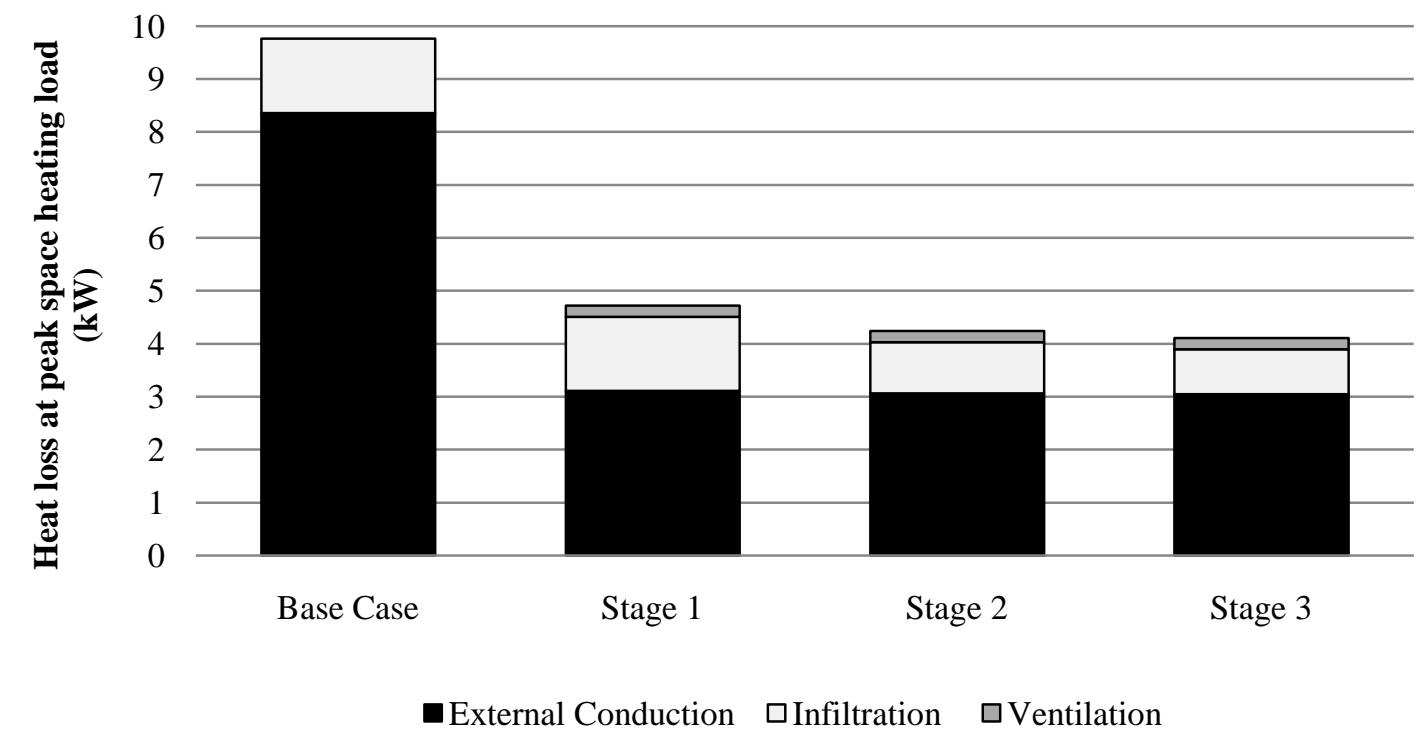

Fig. 1. E.On house heat loss at peak space heating load

Figure 2 details the distribution of the annual building's energy consumption, and the percentage reduction achieved after applying the series of retrofit measures. The MVHR system installed in stage 1 contributes to an increase in auxiliary energy, but the impact is minimal in this instance because of the considerable reduction in space heating due to the thermal upgrades. Stage 2 and stage 3 improvements demonstrate further reductions in annual energy performance, totalling $64 \%$ as a result of the improvements to the building air tightness and heat recovery efficiency.

Although stage 3 displays lower building energy consumption compared to the previous analyses, the comparison is not a fair one as there is debate about the point at which a controlled ventilation strategy becomes necessary. BRE Digest $398^{12}$ advises that a whole house ventilation strategy should maintain an air change rate of $0.5 \mathrm{ach}^{-1}$, less the background infiltration rate. Applying Kronvall's rule, a tested air change rate of $13.65 \mathrm{ach}^{-1}$ corresponds $^{-1}$ to a background infiltration rate of $0.68 \mathrm{ach}^{-1}$ for the E.On house, indicating that a forced ventilation system is unnecessary. If the MVHR system was not included in stage 1 and stage 
2 analyses, the building energy consumption would be lower as the auxiliary energy would decrease, and the lack of ventilation losses would mean less demand on the space heating. Stage 3 therefore does not necessarily demonstrate an improved energy performance compared to less airtight buildings when they are considered without a forced ventilation strategy.

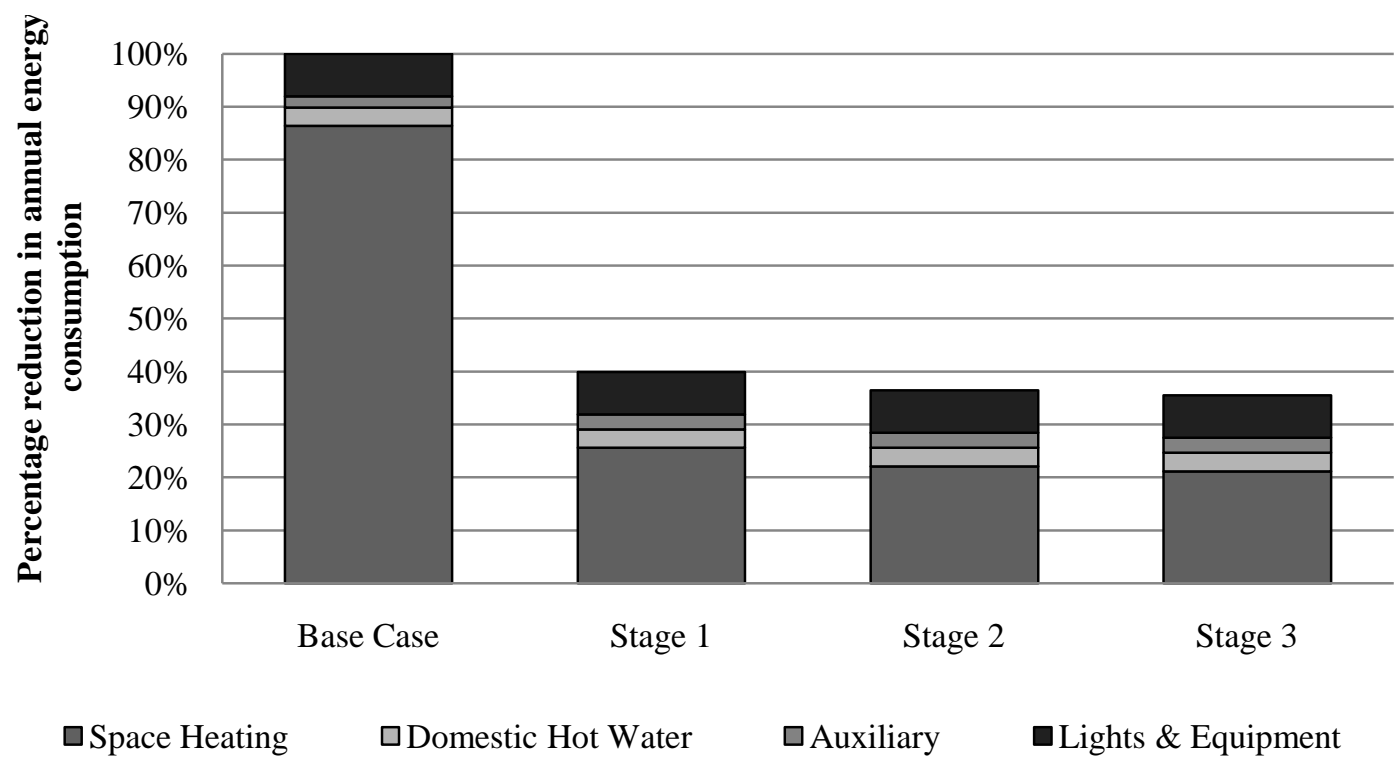

Fig. 2. E.On house percentage reduction in annual building energy consumption

\subsection{Impact of building air permeability on the thermally improved E. On House}

The second investigation assesses the impact on the performance of the E. On house if future draught-proofing measures were able to achieve lower air permeability values. A ventilation strategy was applied based on the guidance outlined in Approved Document $\mathrm{F}^{13}$, detailed in table 2. The results are compared against a naturally ventilated E.On house, at an air permeability of $10 \mathrm{~m}^{3} / \mathrm{m}^{2} \cdot \mathrm{h}$ at $50 \mathrm{~Pa}$.

Table 2. Building Regulation Criteria

\begin{tabular}{|c|c|c|c|}
\hline Standard & Criterion & $\begin{array}{l}\text { Infiltration } \\
\text { Reduction }\end{array}$ & $\begin{array}{c}\text { E.On House } \\
\text { Ventilation Flow } \\
\text { Rate (1/s) } \\
\end{array}$ \\
\hline $\begin{array}{c}\text { Approved Document F } \\
\text { (Air permeability }>5 \mathrm{~m}^{3} / \mathrm{m}^{2} . \mathrm{h} \text { ) }\end{array}$ & $0.3 \mathrm{l} / \mathrm{s} / \mathrm{m}^{2} *$ & $\begin{array}{c}0.04 \times \text { gross } \\
\text { internal volume }\end{array}$ & $21 \mathrm{l} / \mathrm{s}$ \\
\hline $\begin{array}{c}\text { Approved Document F } \\
\text { (Air permeability }<5 \mathrm{~m}^{3} / \mathrm{m}^{2} . \mathrm{h} \text { ) }\end{array}$ & $0.3 \mathrm{l} / \mathrm{s} / \mathrm{m}^{2} *$ & $\mathrm{n} / \mathrm{a}$ & $30 \mathrm{l} / \mathrm{s}$ \\
\hline
\end{tabular}

The introduction of the ventilation flow rate initially increases the E.On house heat losses at the time of the peak space heating load (Figure 3), however the combined effects of the MVHR system and improvements to the building air tightness to achieve $7 \mathrm{~m}^{3} / \mathrm{m}^{2} . \mathrm{h}$ at $50 \mathrm{~Pa}$ decrease the infiltration by enough to reduce the overall heat loss to less than the naturally ventilated case.

The ventilation losses are greater for the last two analyses, but it should be noted that the peak space heating load occurs at a different time for these from the first three analyses. The 
ventilation losses are dependent on the temperature difference between the supply air and the room temperature, which vary over the course of the day depending on the room use. This means the peak ventilation loss does not necessarily coincide with the peak space heating load. As a result, figure 3 shows that improving the building air permeability to $5 \mathrm{~m}^{3} / \mathrm{m}^{2}$.h or less reduces the infiltration losses by enough to move the peak space heating load to a different time, when the ventilation losses form a greater proportion of the total heat loss.

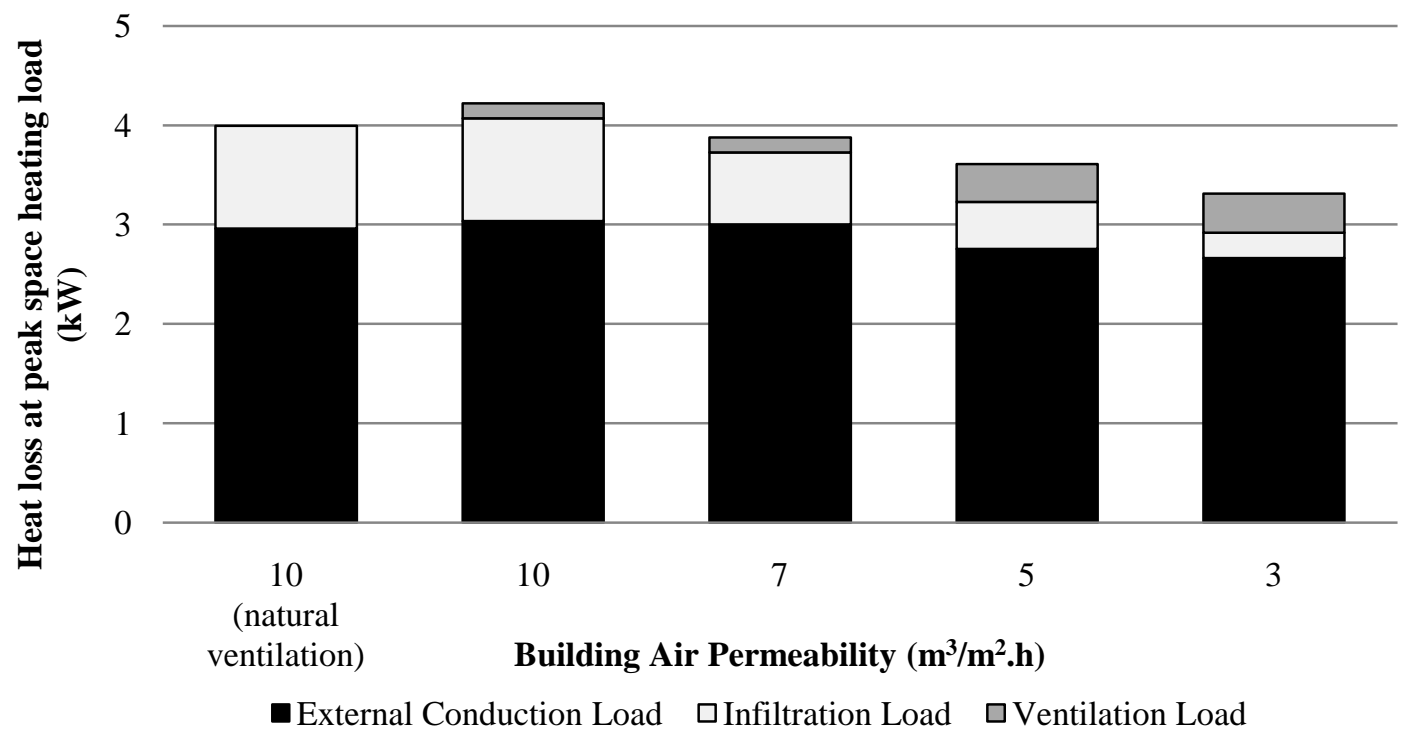

Fig. 3. Heat loss at peak space heating load for improving building air permeability

The annual energy consumption associated with the operation of the building is attributable to the space heating, auxiliary energy (e.g. pumps and fans), domestic hot water, lighting and equipment. The last three parameters are related to occupancy behavior, and predefined by the room templates. Based on the assumption that there is no change in occupancy behavior, table 4 reports the annual energy consumption associated with the space heating and auxiliary systems for the E.On house at different air permeability values. Table 4 details values associated with the E.On house for a natural ventilation strategy with an air permeability of $10 \mathrm{~m}^{3} / \mathrm{m}^{2} . \mathrm{h}$ at $50 \mathrm{~Pa}$, an MVHR system specified to minimum building standards and an MVHR system specified to best practice standards. Table 3 gives the performance parameters of system components associated with these strategies.

Table 3. Performance parameters of system components

\begin{tabular}{ccc}
\hline Component & $\begin{array}{c}\text { Minimum Building } \\
\text { Standards }^{14}\end{array}$ & Best Practice $^{15}$ \\
\hline $\begin{array}{c}\text { Specific Fan Power } \\
\text { (Exhaust Only) }\end{array}$ & $0.5 \mathrm{~W} / \mathrm{/} / \mathrm{s}$ & $\mathrm{n} / \mathrm{a}$ \\
\hline $\begin{array}{c}\text { Specific Fan Power (Whole } \\
\text { House Ventilation) }\end{array}$ & $1.5 \mathrm{~W} / \mathrm{l} / \mathrm{s}$ & $1 \mathrm{~W} / \mathrm{l} / \mathrm{s}$ \\
\hline Heat Recovery Effectiveness & $70 \%$ & $85 \%$ \\
\hline
\end{tabular}

The introduction of the MVHR system increases auxiliary energy consumption, and initially increases the space heating energy as a result of forcing an increased building air change rate which places an additional load on the boiler. The combined effects of improved building air tightness and effective heat recovery need to reduce the space heating energy by enough to negate the increase in auxiliary energy. 
For an MVHR system specified to minimum building standards, a reduction in annual energy is achieved when the building air permeability has been improved to $3 \mathrm{~m}^{3} / \mathrm{m}^{2}$.h at $50 \mathrm{~Pa}$, compared to the naturally ventilated case.

In contrast, an MVHR system operating at best practice standards achieves the break-even point at an air permeability of $7 \mathrm{~m}^{3} / \mathrm{m}^{2}$.h at $50 \mathrm{~Pa}$. Further improvements contribute to overall energy savings, with an air permeability of $3 \mathrm{~m}^{3} / \mathrm{m}^{2} . \mathrm{h}$ at $50 \mathrm{~Pa}$ achieving a $10 \%$ reduction in the combined annual space heating and auxiliary energy from the naturally ventilated case.

However, an energy reduction does not directly equate to a $\mathrm{CO}_{2}$ reduction because of the higher carbon intensities associated with electricity compared to gas. The combined effects of reduced air permeability and MVHR must reduce the space heating energy by nearly three times the increase in auxiliary energy to ensure a net reduction in $\mathrm{CO}_{2}$ emissions. Improving the building air permeability to $3 \mathrm{~m}^{3} / \mathrm{m}^{2}$.h at 50 Pa successfully realises a total reduction in $\mathrm{CO}_{2}$ emissions for the E.On house when the MVHR equipment is specified to both minimum and best practice standards, though the saving is more significant for the latter.

Table 4. Annual space heating and auxiliary energy consumption for improving air permeability

\begin{tabular}{|c|c|c|c|c|c|}
\hline \multicolumn{2}{|c|}{$\begin{array}{l}\text { Building Air Permeability at } \\
50 \mathrm{~Pa}\left(\mathrm{~m}^{3} / \mathrm{m}^{2} . \mathrm{h}\right)\end{array}$} & 10 & 7 & 5 & 3 \\
\hline \multirow{3}{*}{$\begin{array}{l}\text { Naturally Ventilated } \\
\text { Building }\end{array}$} & $\begin{array}{l}\text { Space Heating } \\
\left(\mathrm{kWh} / \mathrm{m}^{2}\right)\end{array}$ & 85.19 & - & - & - \\
\hline & $\begin{array}{l}\text { Auxiliary } \\
\left(\mathrm{kWh} / \mathrm{m}^{2}\right)\end{array}$ & 9.55 & - & - & - \\
\hline & $\begin{array}{l}\text { Combined } \\
\left(\mathbf{k W h} / \mathbf{m}^{2}\right)\end{array}$ & 94.74 & - & - & - \\
\hline \multirow{3}{*}{$\begin{array}{l}\text { Minimum Building } \\
\text { Standards MVHR } \\
\text { equipment }\end{array}$} & $\begin{array}{l}\text { Space Heating } \\
\left(\mathrm{kWh} / \mathrm{m}^{2}\right)\end{array}$ & 96.67 & 85.83 & 83.42 & 76.32 \\
\hline & $\begin{array}{l}\text { Auxiliary } \\
\left(\mathrm{kWh} / \mathrm{m}^{2}\right)\end{array}$ & 11.83 & 11.83 & 12.72 & 12.72 \\
\hline & $\begin{array}{l}\text { Combined } \\
\left(\mathbf{k W h} / \mathbf{m}^{2}\right)\end{array}$ & 108.50 & 97.66 & 96.13 & 89.04 \\
\hline \multirow{3}{*}{$\begin{array}{c}\text { Best Practice } \\
\text { Standards MVHR } \\
\text { equipment }\end{array}$} & $\begin{array}{l}\text { Space Heating } \\
\left(\mathrm{kWh} / \mathrm{m}^{2}\right)\end{array}$ & 94.67 & 83.92 & 80.72 & 73.73 \\
\hline & $\begin{array}{l}\text { Auxiliary } \\
\left(\mathrm{kWh} / \mathrm{m}^{2}\right)\end{array}$ & 10.81 & 10.81 & 11.40 & 11.40 \\
\hline & $\begin{array}{l}\text { Combined } \\
\left(\mathrm{kWh} / \mathrm{m}^{2}\right)\end{array}$ & 105.48 & 94.73 & 92.12 & 85.13 \\
\hline
\end{tabular}

\section{Conclusion}

The modelling indicates that the application of all the retrofit measures detailed in table 1 have successfully reduced the energy consumption associated with the E.On house by $64 \%$ compared to the initial 1930's base case scenario.

An MVHR system operating at minimum building standards achieves an overall reduction in building energy consumption compared to the naturally ventilated case only when the air permeability has been reduced to $3 \mathrm{~m}^{3} / \mathrm{m}^{2}$.h at $50 \mathrm{~Pa}$, based on the E. On house which has been thermally upgraded.

On the other hand, an MVHR system operating at best practice standards can equal the energy performance of the naturally ventilated case when an air permeability of $7 \mathrm{~m}^{3} / \mathrm{m}^{2} . \mathrm{h}$ at $50 \mathrm{~Pa}$ is 
achieved. Further improvements to the building air tightness to achieve $5 \mathrm{~m}^{3} / \mathrm{m}^{2}$.h at $50 \mathrm{~Pa}$ or less will contribute to net energy savings.

The results from the modelling show that the building airtightness plays a critical role in achieving a reduction in building energy consumption, and more significantly $\mathrm{CO}_{2}$ emissions. The difficulties experienced by the E.On house in improving the building air tightness suggest that the challenge of achieving the necessary air permeability should not be under-estimated, and the practicalities should be carefully considered when addressing existing dwellings in the UK.

\section{References}

[1] Energy Saving Trust, Energy-efficient refurbishment of existing housing (CE83), EST, 2003.

[2] www.calebre.org.uk (accessed 28/1/11).

[3] M. Sherman et al, Building airtightness: research and practice, Lawrence Berkeley National Laboratory, LBNL-53356, 2003.

[4] R.K. Stephen, Airtightness in UK Dwellings: BRE’s Test Results and Their Significance, Report 359, Building Research Establishment, 1998.

[5] P. Carrer et al, Allergens in indoor air: environmental assessment and health effects, The Science of the Total Environment, 2001, 270(1-3): 33-42.

[6] H.B. Awbi, Ventilation of buildings, Spon, Second Edition, 2003, pp. 37- 45.

[7] www.2010ncm.bre.co.uk (accessed 28/1/11)

[8] Chartered Institute of Building Services Engineers, Testing buildings for air leakage, CIBSE, 2000.

[9] J. Kronvall, Testing of houses for air leakage using a pressure method, ASHRAE Transactions, 1978, 84(1): 72-9

[10]C. Dubrul, Inhabitants behavior with respect to ventilation, UK: Air Infiltration Centre, Technical Note 23, 1988.

[11]M. Sherman, Estimation of infiltration from leakage and climate indicators, Energy and Buildings, 1987, 10(1): 81-6.

[12]J. Jokisalo et al, Building leakage, infiltration and energy performance analyses for Finnish detached houses, Building and Environment, 2009, 44(2): 377-387.

[13]Building Research Establishment, Continuous mechanical ventilation in dwellings, BRE, Digest 398, 1994.

[14]Department for Communities and Local Government, Approved Document F: Means of Ventilation, NBS, 2010.

[15]Department for Communities and Local Government, Domestic Building Services Compliance Guide, NBS, 2010.

[16]Energy Saving Trust, Energy efficient ventilation in dwellings - a guide for specifiers, EST, 2006. 